\title{
INTANGIBLE-DRIVEN PERFORMANCE: TWO DECADES SEARCHING FOR THE PHILOSOPHER'S STONE
}

\author{
E. A. SHAKINA \\ International Laboratory of Intangible-driven Economy, \\ National Research University Higher School of Economics, St. Petersburg, Russia ${ }^{\text {a }}$ \\ M. A. MOLODCHIK, P. A. PARSHAKOV \\ International Laboratory of Intangible-driven Economy, \\ National Research University Higher School of Economics, Perm, Russia ${ }^{b}$
}

\begin{abstract}
The study offers a structural literature review on the twenty years the evolution of the fast-growing research topic of intellectual capital (IC) and intangible-driven performance. Despite a rather short independent history, the IC concept has undergone a substantial transformation, bringing to the discussion vast empirical and methodological literature. Several endeavors carrying out literature review studies could only partially satisfy the needs of the systematization of the relevant research. Hence, there is still a large room for such kind of analysis due to the increasing number of new papers published in the area and puzzle of IC-related sophistications. To draw a holistic picture of the landscape of IC and associated corporate performance, this study departures from the mixed research methodology embracing elements of machine-learning tools and in-depth qualitative interpretation of obtained results and critical discussion of the most influential studies in the field. Our findings demonstrate that four professional outlets selected for the examination have generated four relatively isolated research topics: "Human capital and performance", "Knowledge sharing, organizational learning: processes that drive performance", "IC and knowledge management for business performance", "Measurement, disclosure of IC and knowledge for business performance". All these research lines are welcomed by all leading journals in the field, having high potential to create a dense flow of conceptual and empirical contributions and practical value for a knowledge-intensive business.
\end{abstract}

Keywords: literature review, intangible-driven performance, text-mining, topic modeling.

JEL: J24, L25, O34.

The reported study was funded by RFBR, project number 19-110-50417.

Postal Addresses: a $3 \mathrm{~A}$, ul. Kantemirovskaya, International Laboratory of Intangible-driven Economy, National Research University Higher School of Economics, St. Petersburg, 194100, Russia; b 37 , bul. Gagarina, International Laboratory of Intangible-driven Economy, National Research University Higher School of Economics, Perm, 614000, Russia

(c) E. A. Shakina, M. A. Molodchik, P. A. Parshakov, 2020

https://doi.org/10.21638/spbu18.2020.307 


\section{INTRODUCTION}

Since the late 1990s and early 2000s, there has been an increasing interest in the phenomenon of intangibles as drivers of corporate performance. This is primarily due to the transition to a new stage of economic evolution, called the knowledge economy, where intangible resources play a pivotal role in achieving success. Looking back for over 20-25 years, we may witness the main reason for this transition. The share of the capitalization of intangibles of the largest corporations and multinationals in SP-500 has been gradually growing since the middle 1970s [Intangible Asset Market Value Study, 2017]. However, a significant surge from 30 to about $70 \%$ was seen in 1995 [Intangible Asset Market Value Study, 2017]. The designated research line has been triggered and is associated with the studies by [Edvinsson, Malone, 1997; Bontis, 1998; Petty, Guthrie, 2000]. The crucial distinction of this research refers to a newborn concept of intellectual capital (IC). This has onwards generated numerous empirical exercises, conceptual papers, and methodological guidelines. Importantly that practically all research hypotheses, metrics, and methods have been borrowed from neighboring disciplines and areas of expertise and made IC concept occupy an intermediate position between economics, management, accounting, and corporate finance.

J. Dumay and T. Garanina [Dumay, Garanina, 2013] consider the period from the middle of the 1990s until the beginning of the 2000 s, the initial stage of academic advancements on IC. This stage rebooted related management theories, such as resource-based view [Barney, 1991; Grant, 1991], dynamic capabilities [Teece, Pisano, Shuen, 1997], behavior firm theory [Greve, 2003].

Due to intangibles-driven shifts, substantial rethinking has been required for overall firm theory, corporate finance, and asset evaluation. Currently, value-based management [Young, O’Byrne, 2000; Ittner, Larcker, 2001; Molodchik, Shakina, Bykova, 2012;
Shakina, Molodchik, 2014] is seen one of the most closely intangible-related corporate concepts. It has opened heated debates around corporate performance driven by intangibles and created vast empirical literature drifting from a simple production function [MingChin, Shu-Ju, Yuhchang, 2005; Shakina, Barajas, 2012; 2014] to multilevel specifications under different economic and institutional contexts [Naidenova, Parshakov, 2013; Molodchik, Jardon, Bykova, 2019]. Hence, the evident complications of the applied methodology and contradictions in the obtained empirical results can be considered links in the chain.

For a better understanding of the evolution and further development of the knowledge on intangible-driven performance, the complex structural literature review must be a valuable contribution. Despite several attempts carrying out literature reviews on intellectual capital and related corporate performance like those by [Serenko, Bontis, 2013; Inkinen, 2015; Snyder, 2019; Bellucci et al., 2020], the holistic picture is far from being completed. It makes this research field eclectic and not systematically studied. Meanwhile, the current advancement in machinebased analysis of narrative information opens new opportunities to objectively explore trends and future perspectives of this research field development. One of the latest contributions which represents this approach is published by [Asmussen, Møller, 2019].

This paper likewise departures from the progressive literature review methodology based on a machine content analysis and seeks to contribute to a more profound understanding of the key topics and methodology advancements in empirical research on intangibles and companies' performance. Meanwhile, it brings together elements of quantitative text-mining procedures and critical qualitative analysis of the most influential studies carried out in the field. Thus, this literature review leans on so-called mixed research methodology with elements of scientometrics; and aims at systematizing and structuring the research landscape in

PЖM 18 (3): 433-456 (2020) 
IC and intangible-driven corporate performance.

The search for relevant works is carried out in the Scopus and Web of Science databases limited by four professional academic journals - Journal of Intellectual Capital, Journal of Knowledge Management, Management Decision, and Measuring Business Excellence. These outlets have been selected due to their high representativeness in the ICrelated research field. Moreover, notable that two journals - Journal of Intellectual Capital, Journal of Knowledge Management - can be considered leading outlets in a narrow field that have demonstrated unprecedently rapid development during the main period of academic advancements in IC. Management Decision and Measuring Business Excellence, meanwhile, position themselves in the general interest scope of management studies having evident preferences for publication of IC studies. The comparative analysis of IC-centered papers in these journals during the last 20 years may draw a representative picture of what has been achieved in this research field and which trends can be expected in the nearest future.

The expected contribution of this literature review can be divided into parts which correspond with the following sections of the remainder of this paper. First, a brief retrospective analysis of the IC-related research is given. Second, the objective comparative dynamics drawn on confirmatory content analysis can demonstrate which topics have been explored, and methods have been adopted across target journals during the investigated period. Third, based on exploratory content analysis of the abstract, the topic modeling is performed to identify clusters of the most relevant research endeavors. Forth, the most impactful papers within each of the clusters have been profoundly analyzed and discussed to show the state-of-the-art and age of the development of the subarea of IC-related research. Based on these findings, the overall picture is drawn in the concluding part. Moreover, perspective research areas are anticipated in the research field around IC and associated corporate performance.

\section{BRIEF HISTORY OF DEVELOPMENT OF THE INTELLECTUAL CAPITAL CONCEPT}

During the last two decades, the IC concept has been developed through four stages [Dumay et al., 2017]. The first stage focused on the awareness of IC importance in creating and managing a sustainable competitive advantage. The second stage was mostly devoted to empirical proofs and the development of accounting metrics for better IC management. Further scholars digging deeper into specific aspects of IC and tried to find out IC implications for different types of organizations. The fourth stage proposed an extension of IC understanding through a holistic view on wealth creation and IC role for society development beyond the organizational boundaries. Recently, two well-known IC scholars [Dumay, Guthrie, 2019] claimed to the fifth stage of IC research, when the boundaries are removed, and the questions asked to change from "What is IC worth to investors, customers, society and the environment?" to "Is managing IC a worthwhile endeavor?" Such a critical point of view might be connected with a frustration considering IC disclosure. At the same time, one could observe the worldwide development of integrated reporting ${ }^{1}$, elaboration of standards for non-financial information disclosure. Moreover, in 2018 the requirements for Knowledge Management Systems were established in the form of international standards issued by ISO $30401^{2}$. The rapid development of the IC-related field, from its emergence to the standards,

\footnotetext{
${ }^{1}$ Integrated Reporting. URL: https://integratedreporting.org; GRI. URL: https://www.globalreporting.org (accessed: 17.09.2020).

${ }^{2}$ ISO. URL: https://www.iso.org/standard/ 68683.html (accessed: 17.09.2020).
} 
motivated us to step back and turn to the origins of IC research interests.

The history of IC discourse started at the end of the 90th last century and has been marked by two publications in top journals in management and economics. In 1998 the Academy of Management Review published the article "Social capital, intellectual capital, and the organizational advantage" by [Nahapiet, Ghoshal, 1998]. The importance of this study is proved by 8369 citations reported by Scopus in 2020, meaning that many scholars started their IC discovering journey being inspired by this article. In the same year, the American Economic Review published the article "Intellectual Human Capital and the Birth of US Biotechnology Enterprises" by [Zucker, Darby, Brewer, 1998], which is also marked with a high level of citation such as 1210 times. Another top journal - the Organization Science paid attention to the origin of IC and presented a well-known article, "Bridging Epistemologies: The Generative Dance between Organizational Knowledge and Organizational Knowing" by [Cook, Brow, 1999].

Meanwhile, the empirical literature around IC and intangible-driven performance has always been focused on at least two relatively independent areas - value-based management approach, and the other is related to the application of the resourcebased view to the IC concept. The valuebased approach has its origins in the concept of economic profit, which perfectly matches the identification of intangibledriven performance. The current stage of the development of the value concept is associated with the studies by [Stern, Shiely, Ross, 2001; Zaratiegui, 2002; Burgman, Roos, 2004]. These conceptual contributions have been followed by many empirical papers like those by [Molodchik, Shakina, Bykova, 2012; Shakina, Molodchik, 2014; Delbecque et al., 2015; Shakina, Barajas, 2014; 2015; 2016; Barajas et al., 2017; Osinski et al., 2017] aimed at finding additional evidence that IC has a high potential for creating. A significant part of the empirical attempts seeks to statistical inference between the quantity and quality of intangible resources and the value created for corporate performance, expressed in added market value or generally accepted in research in the field finance by Tobin's $Q$.

These and other IC and knowledge-related publications pushed the initiative for launching two specialized journals such as Journal of Knowledge Management and Journal of Intellectual Capital. After two decades of existence, these journals reached leading positions in the Social science citation index (SSCI), in particular, in 2019 Journal of Intellectual Capital the obtained impact factor is 4.81 and Journal of Knowledge Management - 4.74. Therefore, we have decided to take these journals as top field journals for our literature review.

However, two top field specialized journals would not represent the overall field of IC and intangible-driven performance having a certain bias towards the recent advancements of IC concept but neglecting a more general view on the research problem. Hence, it would be important to address general-interest outlets which focus though on IC studies having a significant impact in the field. The selection of these outlets has been done based on the most frequently mentioned keywords "intellectual capital", "intangible-driven performance", "intangibles", "intellectual capital management". On the intersection of the search results and filtered by the relevant subject areas ("Business, management and accounting", "Economics, econometrics and finance", "Social sciences" and "Decision sciences"), and processed by "Analyze search results" tool in Scopus - two outlets have been selected: Management Decision and Measuring Business Excellence. These two journals having relatively lower scientometric records compared to Journal of Intellectual Capital and Journal of Knowledge Management are, however, well-known and impactful outlets in IC-related research areas. Both journals are included in the 
WoS Core collection Emerging sources citation index (ESCI) ${ }^{3}$.

Importantly that Management Decision has published in 1998 one of the most highly cited paper "Intellectual capital: an exploratory study that develops measures and models" written by [Bontis, 1998]. Later this journal provided profound analysis for IC related definitions and proposed the following:

"Intangibles are strategic firm resources that enable an organization to create sustainable value but are not available to a large number of firms (a rarity). They lead to potential future benefits which cannot be taken by others (appropriability), and are not imitable by competitors, or substitutable using other resources. They are not tradeable or transferable on factor markets (immobility) due to corporate control. Because of their intangible nature, they are non-physical, non-financial, are not included in financial statements, and have a finite life. To become an intangible asset included in financial statements, these resources need to be linked to a company's products and services, identifiable from other resources, and become a traceable result of past transactions" [Kristandl, Bontis, 2007, p. 1518].

This definition of intangibles is now widely used in IC studies. In the current paper, we will also rely on this definition. Taking into account the significant contribution of Management Decision journal for IC investigation, we included it in the literature review.

The journal Measuring Business Excellence was launched at the end of the 1990th as a response to emerge of the knowledge-driven economy, and business demand for new management approaches, in particular, in the field of measuring and reporting of intangibles. Till now, IC measurement and disclosure are under scholar debate and present highly dis-

\footnotetext{
${ }^{3}$ Emerging sources citation index. URL: https:// clarivate.com/webofsciencegroup/solutions/webofscience-esci/ (accessed: 17.09.2020).
}

cussed topics in academic and business society [Dumay, Guthrie, 2019].

\section{LITERATURE REVIEW METHODOLOGY}

As has been stated earlier, the mixed research methodology is seen as a distinction of this literature review. It combines the most relevant tools of machine-based content analysis by adopting the latest advancements in confirmatory and exploratory content analysis, followed by in-depth qualitative discussion of the most impactful papers published in subareas of IC studies. The research design contains three main stages. In the first step, the confirmatory content analysis is carried out to show trends and structural shifts in the following elements of IC-related research: objects of the investigation, adopted methodological approaches and techniques, and metrics of intangible-driven performance as a primary focus of this literature review. The second step is performed through exploratory content analysis, which does not imply any precoding of the narrative constructs for the machine-learning search. The exploratory analysis refers to topic modeling for the objective identification of IC-related subareas of research. Based on the findings of the exploratory content analysis, the qualitative interpretation and critical analysis of the selected studies within each of the subareas are carried out. These three stages determine a contribution and key findings of the literature review proposing future trends in IC-related studies.

For the research, we have collected abstracts of papers published in four leading peer-review academic journals: Journal of Intellectual capital, Journal of Knowledge Management, Measuring Business Excellence, and Management Decisions. During the observed period from 2000 till 2019, there have been more than 4400 papers published in these outlets. As the focus of this review is 


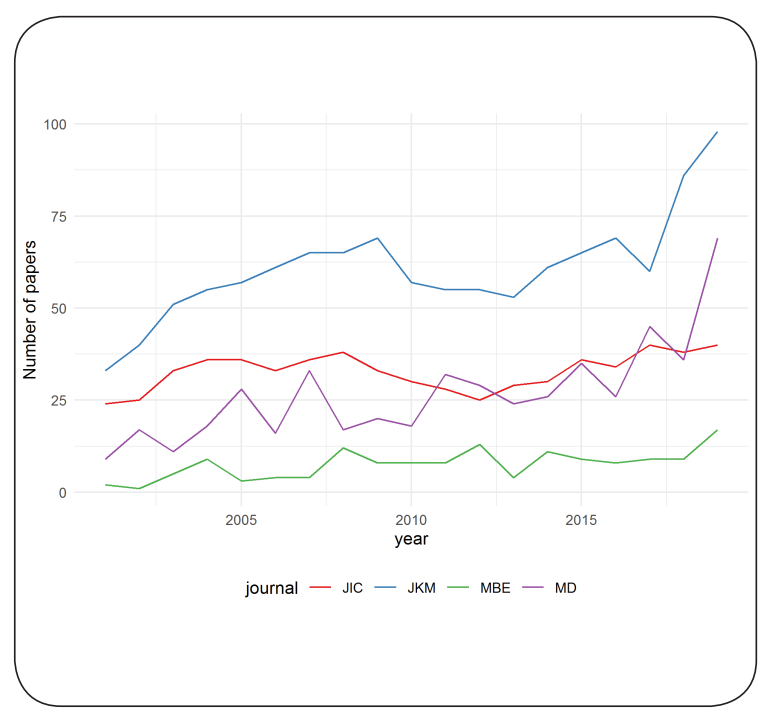

Fig. 1. Number of papers by journal and year

Note: JIC - Journal of Intellectual Capital, JKM - Journal of Knowledge Management, MBE - Measuring Business Excellence, MD - Management Decision.

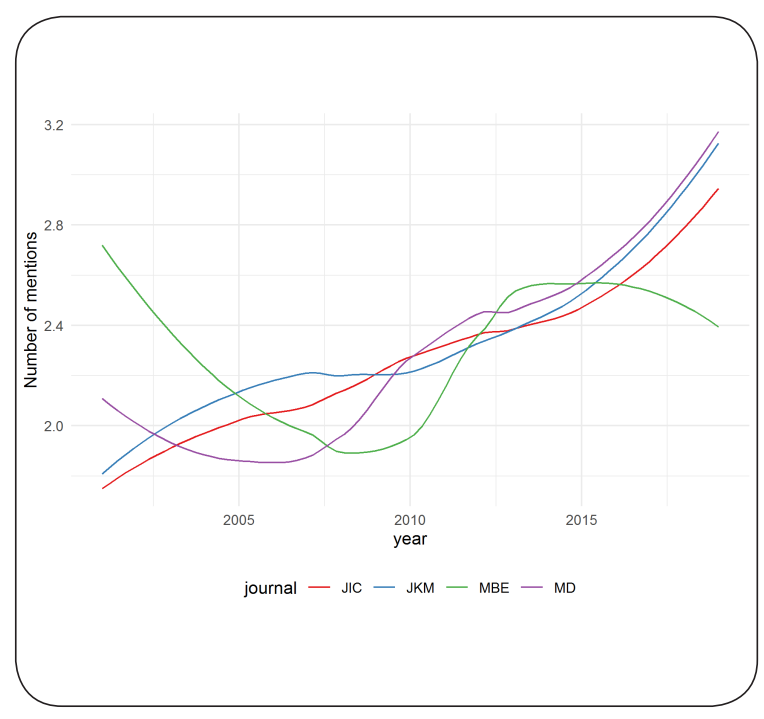

Fig. 2. The average number of authors by journal

Note: JIC - Journal of Intellectual Capital, JKM - Journal of Knowledge Management, MBE - Measuring Business Excellence, MD - Management Decision.
IC, we further analyze only abstracts that contain at least one of the keywords: "intangible", "knowledge", and "intellectual". The number of abstracts containing these keywords is 2432 . The journal with the highest number of abstracts is Journal of Knowledge Management (1 155), Journal of Intellectual Capital is in second place with a much lower number of abstracts (624), Management Decisions has 509 abstracts and Measuring Business Excellence - 144.

Figure 1 demonstrates the dynamics of papers on IC published in the journals, as mentioned above. Here and after in the graphs, we will use the abbreviation of the journals: Journal of Knowledge Management (JKM), Journal of Intellectual Capital (JIC); Management Decisions (MD); Measuring Business Excellence (MBE). First, the gap between journals in the same for almost two decades. Second, one can notice that during the last three years, there is a steady increase in the topic of IC. Figure 2 shows the average number of authors per paper by year and journal, in most of the journals, the average changes from 2 to 3 during the last twenty years. This shows the increasing role of collaboration in management research.

In the next sections, we provide an empirical analysis of this textual data. We here rely on the text mining approach to the literature review [Asmussen, Møller, 2019]. We also divide our analysis into the exploratory and confirmatory, following the paper of [Parshakov, Shakina, 2020], who use text mining to analyze IC disclosure.

\section{CONTENT ANALYSIS RESULTS}

In this section, we rely on the confirmatory textual analysis or content analysis. Content analysis as an approach to text analysis was first described in the 1940s [Krippendorff, 1980]. Usually, researchers use it to justify the presence of particular content. Despite criticism [Krippendorff, 1980; Abeysekera, 2006; Parshakov, Shakina, 2020], content 
Table 1

\section{Coding framework}

\begin{tabular}{|c|c|}
\hline Content & Keyword \\
\hline $\begin{array}{l}\text { Company } \\
\text { type }\end{array}$ & $\begin{array}{l}\text { "SME" (small and medium-sized } \\
\text { enterprises), "large enterprise", } \\
\text { "corporation", "innovative", } \\
\text { "knowledge-intensive" }\end{array}$ \\
\hline $\begin{array}{l}\text { Performance } \\
\text { indicator }\end{array}$ & $\begin{array}{l}\text { "ROA" (return on assets), "EVA" } \\
\text { (economic value added), "MVA" } \\
\text { (market value added), "value", } \\
\text { "profit" }\end{array}$ \\
\hline \multirow{2}{*}{ Methodology } & $\begin{array}{l}\text { Data source: “questionnaire”, “ex- } \\
\text { periment”, “case study", "inter- } \\
\text { view", “survey" }\end{array}$ \\
\hline & $\begin{array}{l}\text { Data processing: “experiment”, } \\
\text { "regression", “machine learning”, } \\
\text { "moderation", “mediation” }\end{array}$ \\
\hline
\end{tabular}

analysis is commonly used in management and, in particular, in the field of IC research.

We have taken the most common keywords which describe company type, performance indicator, and the research methodology. Table 1 presents the coding framework of our content analysis.

Next, we analyze the dynamics of the average number of mentions of a particular keyword by year and a journal.

Firstly, we addressed our attention to the objectives of the analysis, especially on a company-type, explored in studies in each of the targeted journals. Figures 3(a), 3(b), 4(a) and 4(b) illustrate the dynamics of keywords that reflect companies' size and companies' type as a objects of examinations.

As one can notice, there is a rising trend for "innovative" and "SME". This pattern is typical for all four outlets. The relative popularity of "corporation" is low but differs across the journals. IC and knowledge management has a primary goal for new knowledge creation, in other words, to stimulate companies for productive innovation activities. Being more agile, sensitive, and adaptive but highly restricted financially,

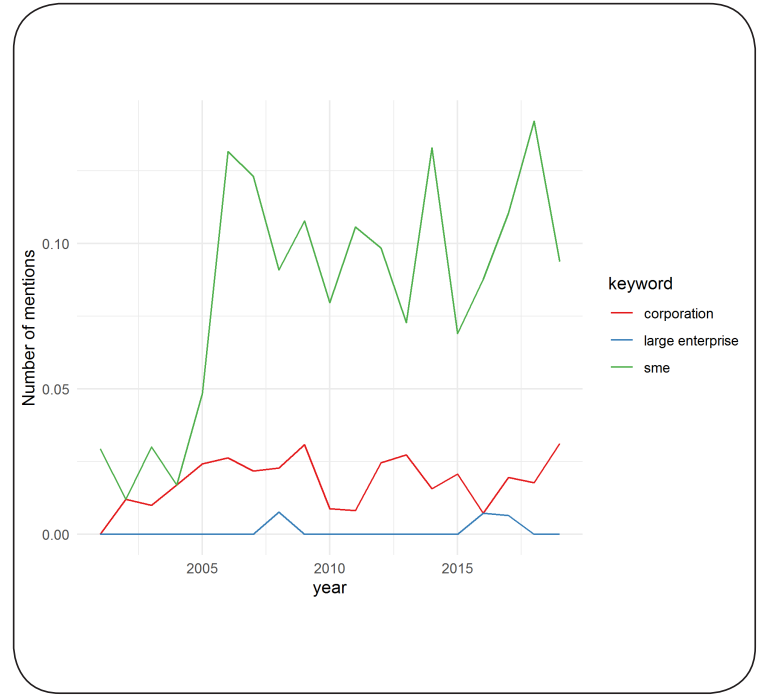

Fig. 3 (a). Total number of mentions of companies' size

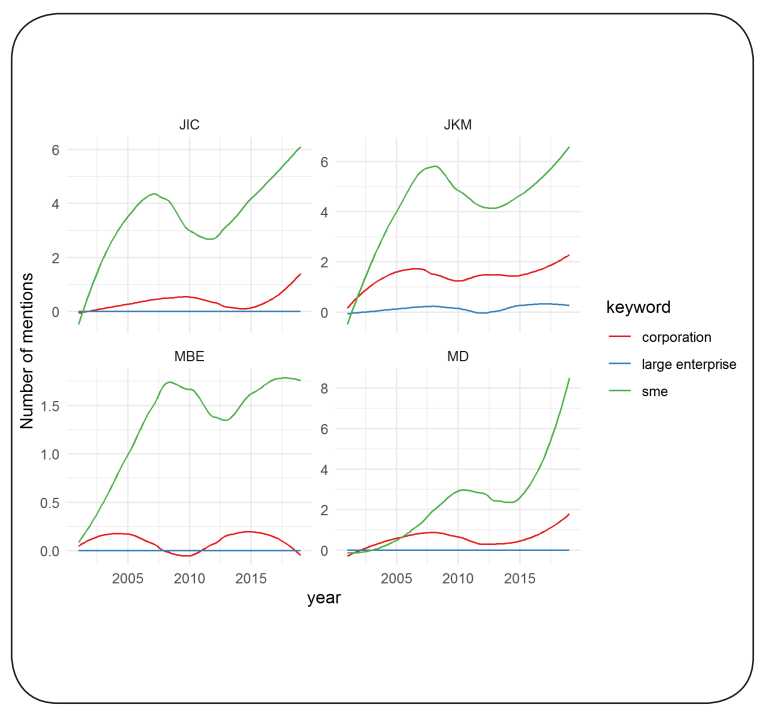

Fig. 3 (b). Number of mentions of companies' size by journals

N ot e: JIC - Journal of Intellectual Capital, JKM - Journal of Knowledge Management, MBE - Measuring Business Excellence, MD - Management Decision. 


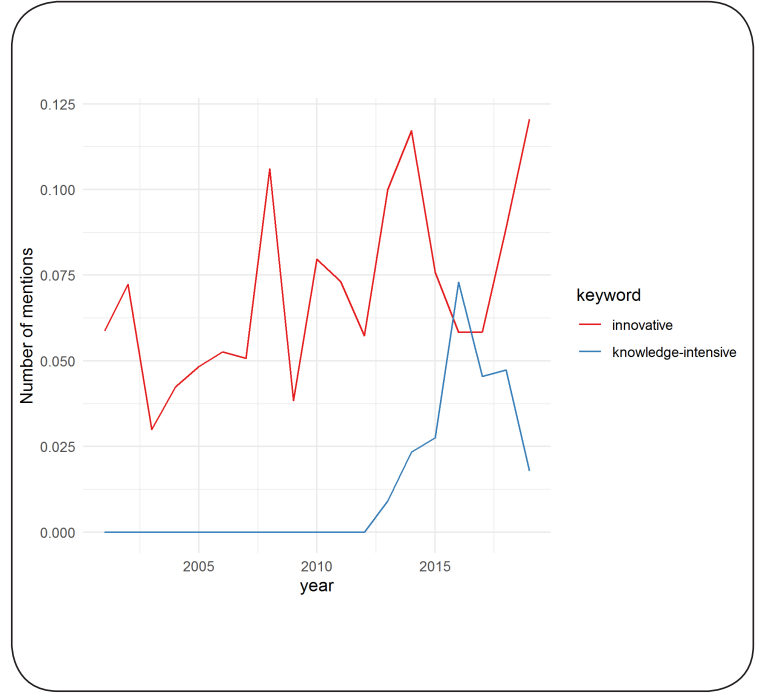

Fig. 4 (a). Total number of mentions of companies' type

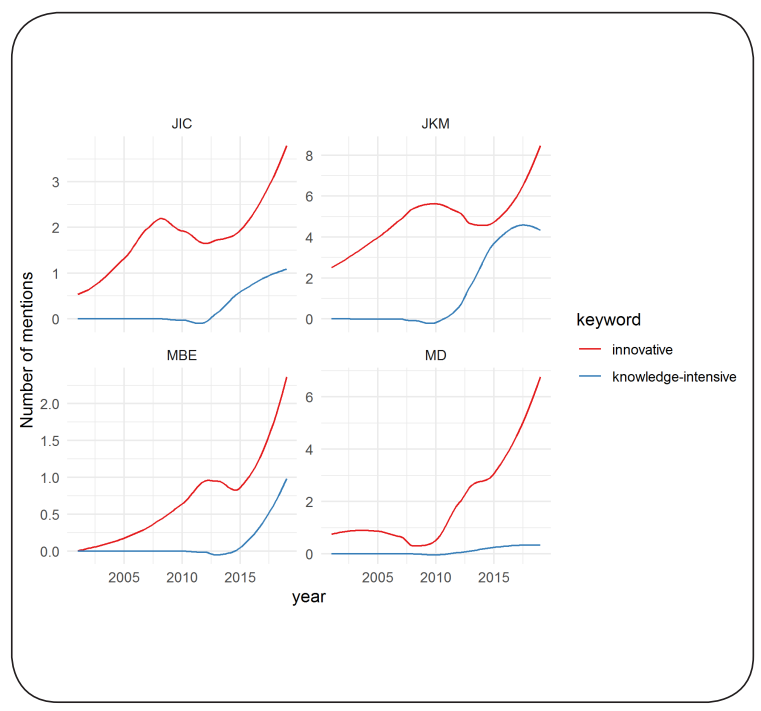

Fig. 4 (b). Number of mentions of companies' type by journals

Note: JIC - Journal of Intellectual Capital, JKM - Journal of Knowledge Management, MBE - Measuring Business Excellence, MD - Management Decision.
SMEs present an appropriate field for IC driven innovations [Molodchik, Jardon, 2017].

Secondly, we have explored the performance metrics analyzed in the papers during the observed period. Hereafter in Figures 5(a) and 5(b), one can see the frequency of keywords, which reflect performance indicators.

"ROA", "EVA", and "value" are by far more prevalent than "MVA", "Tobin's Q" and "profit". "Tobin's Q" and "MVA" are very correlated since they are presenting similar market-based performance. The predominance of the indicator return on assets is explained through its availability for most companies through standard accounting reports. Interestingly, there are differences across the journals. Journal of Intellectual Capital has much more accent on the studies of company value, while the rest of the journals are concentrated on the analysis of ROA. However, in general the popularity of all performance indicators decreased.

The third aspect of content analysis concerns data sources used in the studies. Figures 6(a) and 6(b) report this information.

"Survey" has a positive and rising trend, and this is common for all the journals except for Measuring Business Excellence. "Interview", "case study", "questionnaire" are also popular and have a positive trend. However, "interview", "case study" became less popular during the last years. Together with the rise of "experiment", this might indicate the growing popularity of less manipulative ways to collect data. Experiments are not popular in all journals, and this result is stable across the years. Manual analysis of abstracts revealed that survey data is very often enriched through accounting data of the companies. Also, it should be noted that last ten years the processes of digitalization changed communication techniques of the companies dramatically and created a new source of information called by researchers' involuntary IC disclosure [Dumay, 2016; Cuozzo et al., 2017] such as web news, consumer comments in social networks, etc. 


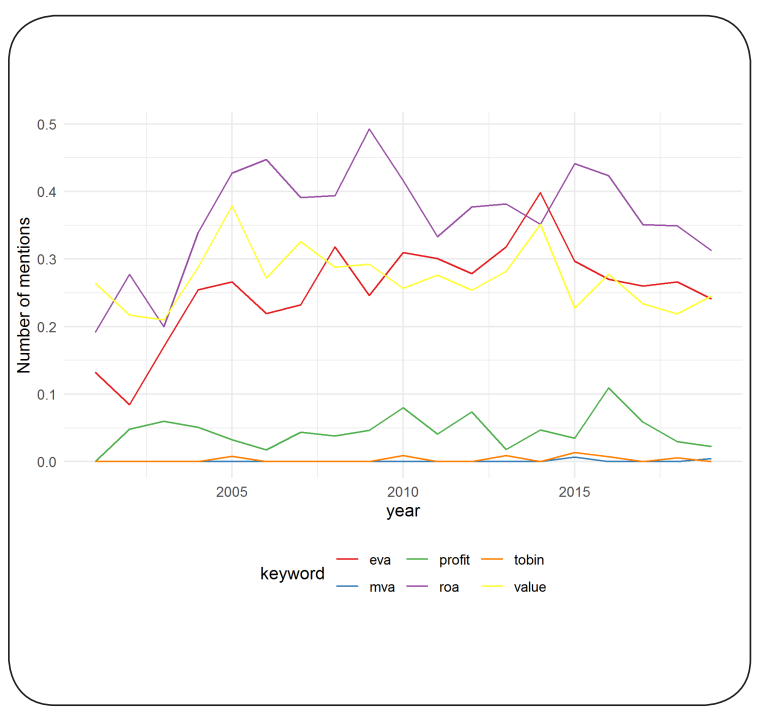

Fig. 5 (a). Type of performance indicator

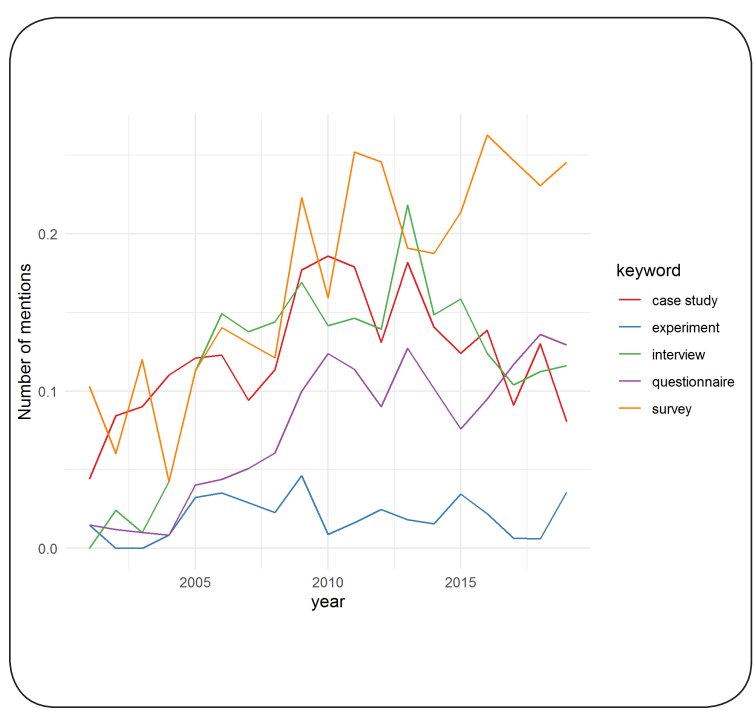

Fig. 6 (a). Type of data source reported by year

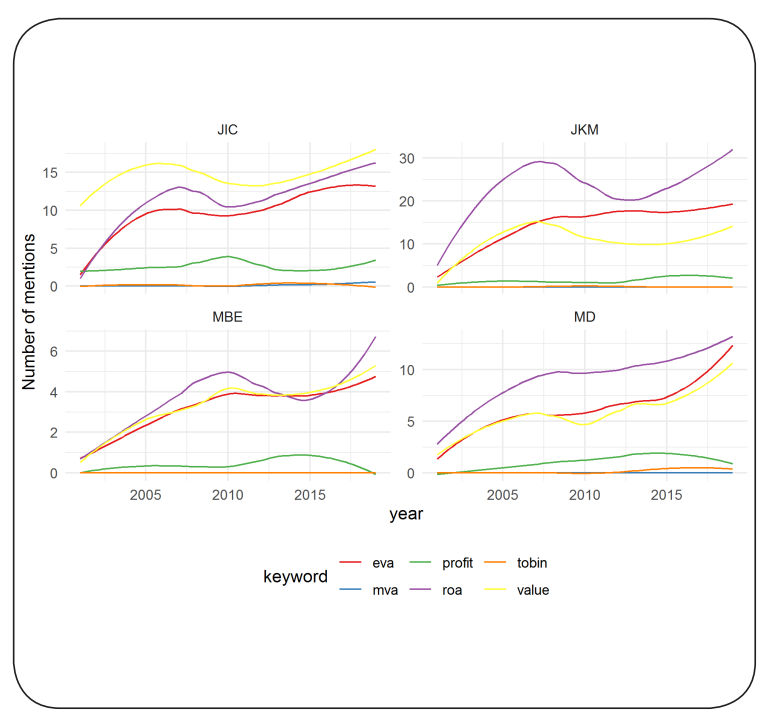

Fig. 5 (b). Type of performance indicator

N ote: JIC - Journal of Intellectual Capital, JKM - Journal of Knowledge Management, MBE - Measuring Business Excellence, MD - Management Decision.

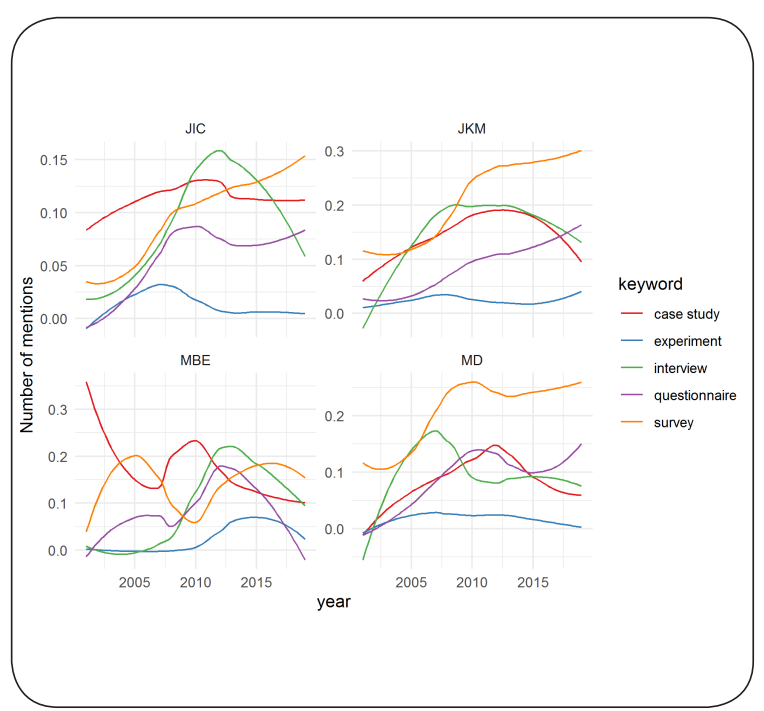

Fig. 6 (b). Type of data source reported by year and journals

Note: JIC - Journal of Intellectual Capital, JKM - Journal of Knowledge Management, MBE - Measuring Business Excellence, MD - Management Decision. 


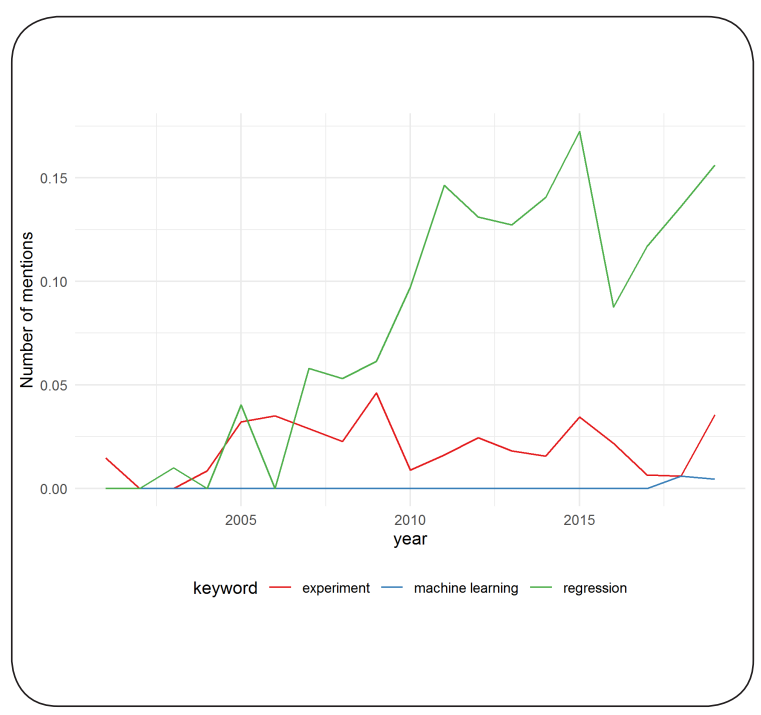

Fig. 7 (a). Type of data processing methods

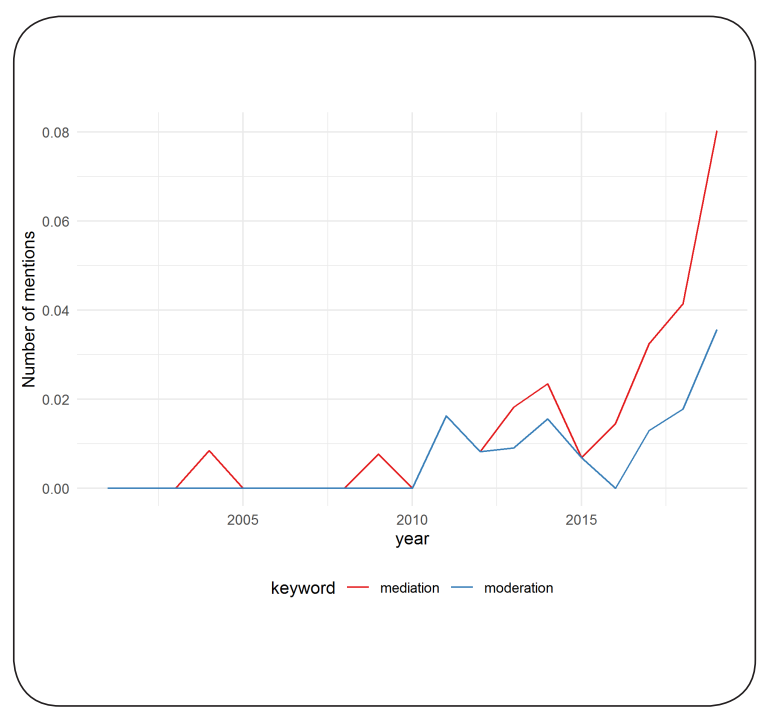

Fig. 8 (a). Type of specific statistical inference

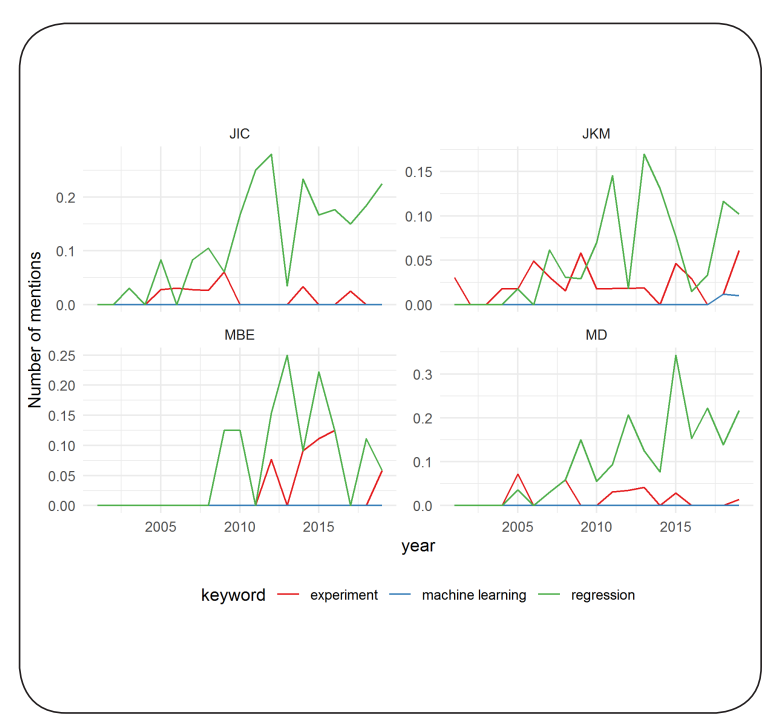

Fig. 7 (b). Type of data processing methods

Note: JIC - Journal of Intellectual Capital, JKM - Journal of Knowledge Management, MBE - Measuring Business Excellence, MD - Management Decision.

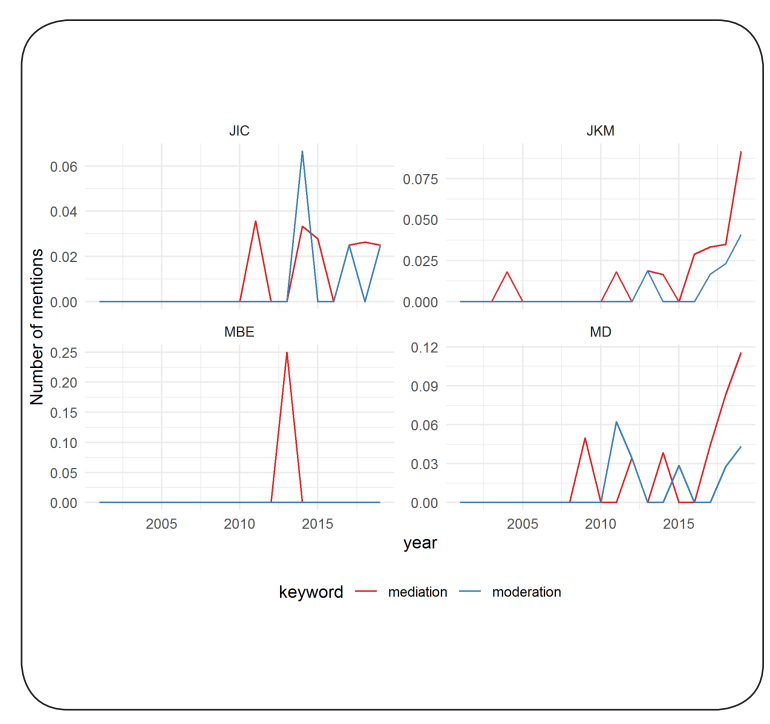

Fig. 8 (b). Type of specific statistical inference

Note: JIC - Journal of Intellectual Capital, JKM - Journal of Knowledge Management, MBE - Measuring Business Excellence, MD - Management Decision. 
Last but not least focus of the content analysis was discovering the methodological approaches used in the papers. Figures 7(a) and 7(b) demonstrate the frequency of the keywords which detects general data processing method. Meanwhile, Figures 8(a) and 8(b) introduce specific statistical inference in IC-related studies.

As one can witness, the regression analysis is by far the most popular approach, and this trend is common for all four journals. The maturity of the IC related field might be illustrated through the upward trend of mediation and moderation effects applied in the framework of regression analysis. It represents a more in-depth analysis of the investigated phenomenon. In the next section devoted to topic modeling, we will show that almost in each topic, mediation and moderation effects are analyzed in recent high cited papers. In the Journal of Knowledge Management, the popularity of mediation analysis is expressed the most. One more insight from figure 6 concerns the evidence that data analysis is rising in the last two years. Together with the slightly declining popularity of regression, it might reflect a shift towards data science techniques in management research.

\section{TOPIC MODELING RESULTS}

In this section, we perform exploratory analysis. We apply topic modeling to the corpus of paper abstracts described above in the data section. Topic modeling is a method for unsupervised classification of text documents [Silge, Robinson, 2016]. The use of topic modeling for a literature review is justified in the paper of [Asmussen, Møller, 2019]. They consider different approaches to text categorization and conclude that topic modeling fits the best. In our analysis, we use Latent Dirichlet allocation, which is one of the strategies to fit a topic model. There are two main assumptions of this method. First, we can treat a text as a mixture of topics.
Second, every topic is treated as a mixture of words.

To apply topic modeling, we need to specify the number of topics. This is similar to determining the number of clusters in the case of numerical data. Since our idea is to use a data-driven approach, the number of topics is chosen based on the statistical tests. Since different tests might give different results, as they found on various assumptions, we use all available tests based both on maximization and minimization routine. In particular, we use two minimization-based tests of [Cao et al., 2009; Arun et al., 2010], and two maximization-based tests of [Griffith, 2010; Deveaud, SanJuan, Bellot, 2014]. The aggregated result is that there are four topics in our corpus of paper abstracts. Fig. 9 presents the words, which are better present each topic. The $\mathrm{x}$-axis represents the probability of belonging to a topic. For a presentation, we report the top 20 words; all the results are available upon a request.

Fig. 9 shows that clusters contain some overlapping words, which means that clusters are contextually close to each other. As we can see, the words "performance", "financial", and "value" are in all clusters, that correspond to the topic of the study and allows including the general word "performance" by naming of all clusters. At the same time, we decided to put attention to those words, which differentiate clusters from each other and take the highest positions in the list. In the first cluster this is the word - "human", in the second - "learning" and "sharing", in the third - "analysis" and "business", in the fourth - "disclosure" and "measurement". Additionally, we relied on our expertise in the field and formulate the names of topics as follows:

Topic 1. Human capital and performance.

Topic 2. Knowledge sharing, organizational learning: processes that drive performance.

Topic 3. IC and KM for business performance.

Topic 4. Measurement, disclosure of IC and knowledge for business performance. 
Cluster 1

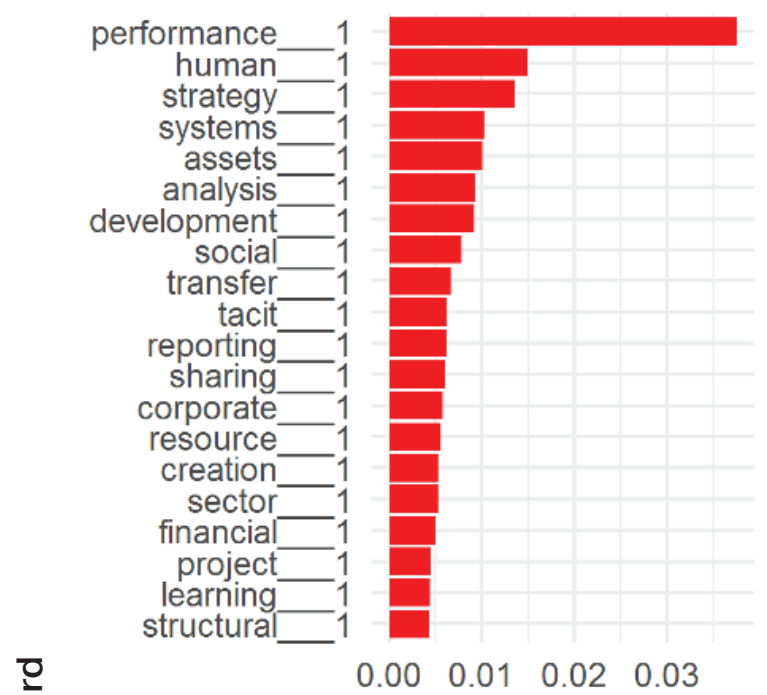

Cluster 3

analysis 3
business 3
information 3
theory 3
human 3
research 3
sharing 3
technology 3
value 3
social 3
communication 3
industry 3
measurement 3
strategy 3
culture 3
networks 3
product 3
financial 3
process 3
systems 3

0.0000 .0050 .0100 .015
Cluster 2
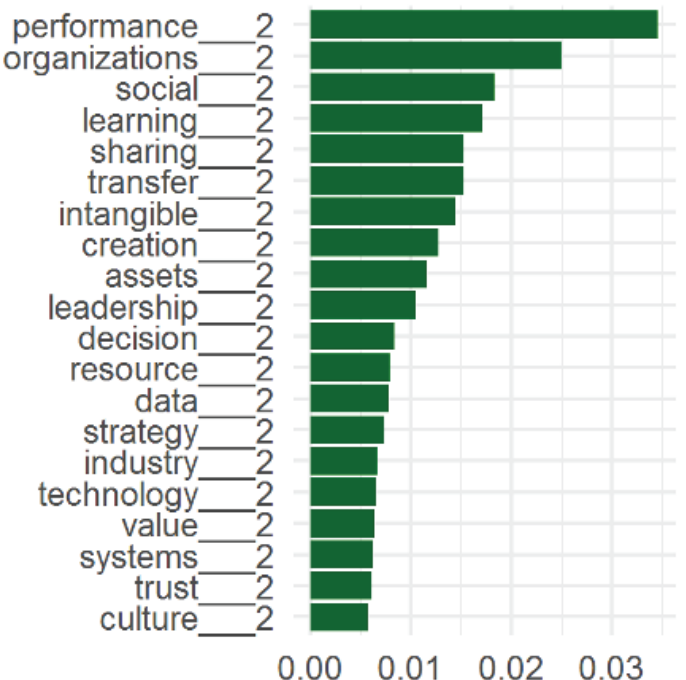

Cluster 4

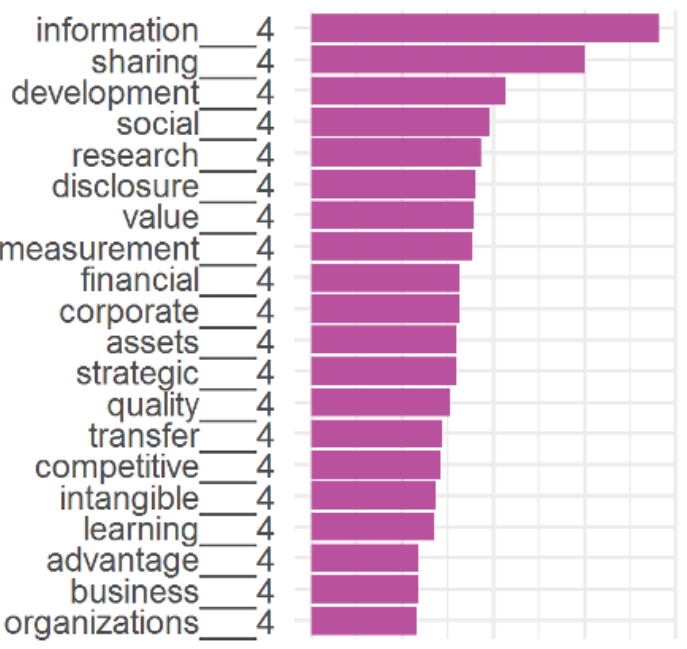

0.0000 .0050 .0100 .0150 .02

Probability to appear in a topic

Fig. 9. Four clusters as a result of topic modeling 
The popularity of four topics is reflected on the Figures 10(a) and 10(b).

For the purpose of the topics' analysis, we have chosen the most cited papers in each journal concerning four revealed topics. These papers were derived from the Scopus report from two lists:

- top 15 cited articles during the last 20 years and;

- top 5 cited articles during 2019-2020.

\section{Topic 1. Human capital and performance}

As one could expect, the topic of Human capital has been revealed to be an isolated topic in IC literature. Very often, human capital is considered to be a primary source of IC [Bontis, Fitz-enz, 2002]. In the framework of this concept, human capital is de-

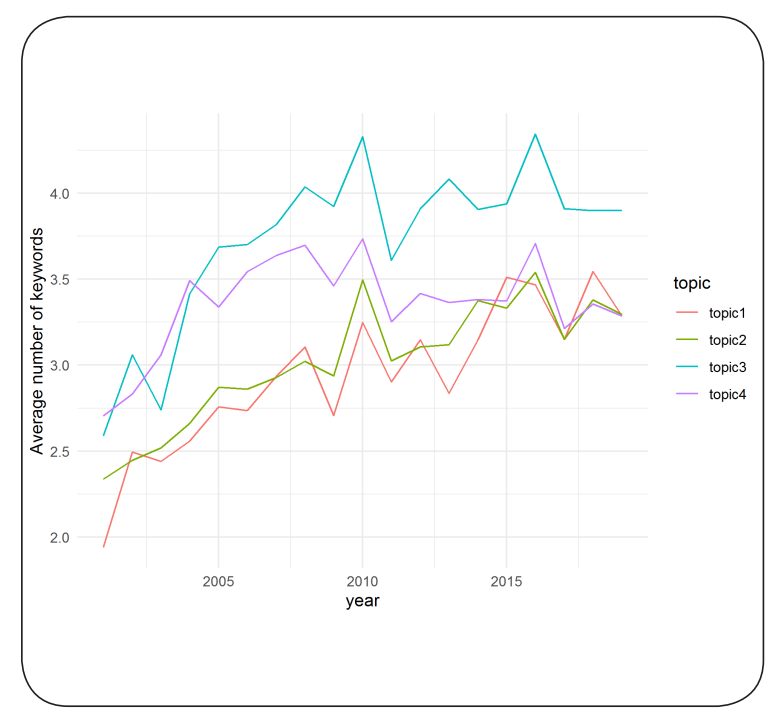

Fig. 10 (a). Average number of keywords related to a topic by year fined through the knowledge, talent, and experience of employees. As noted by [Smith, 2001], leaving employees often take their valuable knowledge, resources, skills, and experiences with them. Those who stay may be assigned new jobs and never use their wealth of accumulated knowledge.

Consequently, scholars and practitioners devoted many efforts to reveal the antecedents of HC emergence, and practices for effective human capital utilization. The literature review shows that some practices were borrowed from the well-developed human resource management field with the aim of their enrichment, considering the crucial role of organizational knowledge for company success. For example, [Yahya, Goh, 2002] proposed that traditional practices of human resource management should be focused on knowledge sharing, creativity, innovative thinking, and leadership skills.

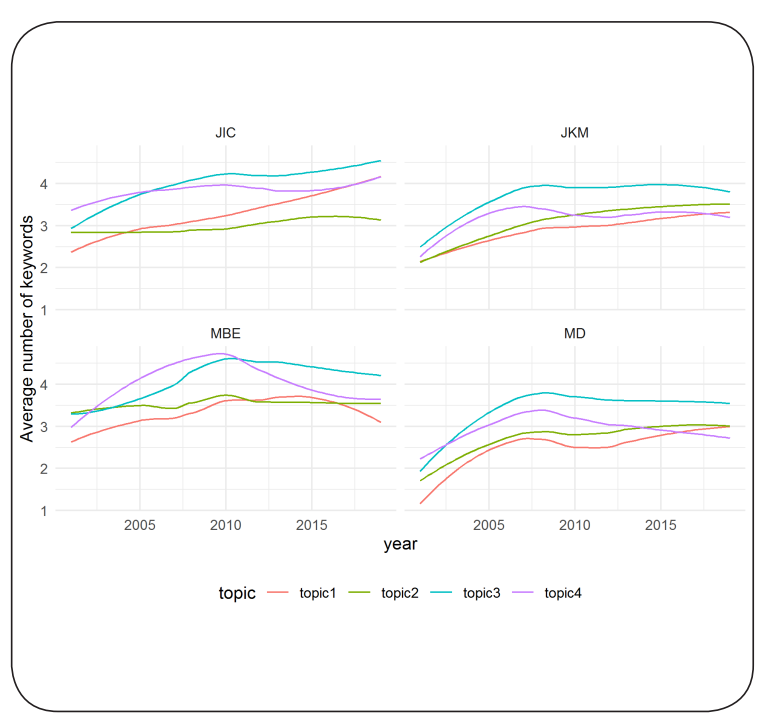

Fig. 10 (b). Average number of keywords related to a topic

Note: JIC - Journal of Intellectual Capital, JKM - Journal of Knowledge Management, MBE - Measuring Business Excellence, MD - Management Decision. 
Three most cited papers on topic 1

\begin{tabular}{|c|c|c|c|}
\hline Author & Journal & Title & Number of citations \\
\hline $\begin{array}{l}\text { [Bhatt, } \\
\text { 2001] }\end{array}$ & $\begin{array}{l}\text { Journal of Knowledge } \\
\text { Management }\end{array}$ & $\begin{array}{l}\text { "Knowledge management in organi- } \\
\text { zations: Examining the interaction } \\
\text { between technologies, techniques, } \\
\text { and people" }\end{array}$ & 597 \\
\hline $\begin{array}{l}\text { [Smith, } \\
\text { 2001] }\end{array}$ & $\begin{array}{l}\text { Journal of Knowledge } \\
\text { Management }\end{array}$ & $\begin{array}{l}\text { "The role of tacit and explicit } \\
\text { knowledge in the workplace" }\end{array}$ & 411 \\
\hline $\begin{array}{l}\text { [Bontis, } \\
\text { Fitz-enz, } \\
\text { 2002] }\end{array}$ & $\begin{array}{l}\text { Journal of Intellectual } \\
\text { Capital }\end{array}$ & $\begin{array}{l}\text { "Intellectual capital ROI: A causal } \\
\text { map of human capital antecedents } \\
\text { and consequents" }\end{array}$ & 366 \\
\hline
\end{tabular}

In table 2 , we present three top-cited articles on topic 1 .

The first paper from table 2, written by [Bhatt, 2001], opened a long-lasting discussion about what kind of dynamic balance between technologies, techniques, and people should find out for leveraging individual knowledge for organizational one and further for company success.

One more intriguing and insightful research avenue in Human Capital (HC) gives tacit knowledge. Being in top from the very beginning (see [Smith, 2001]), tacit knowledge is one of the polar strategic choices in Knowledge Management (KM) dilemma "tacit vs. explicit" knowledge [Jasimuddin, Klein, Connell, 2005].

[Bontis, Fitz-enz, 2002] provided empirical evidence of the causal map of $\mathrm{HC}$ antecedents and consequents, underlining the following:

- managerial leadership is the key antecedents of $\mathrm{HC}$;

- effective IC management yields in higher financial results per employee;

- employee sentiments have an impact on IC, KM, and business performance;

- KM, coupled with HR policies, can decrease turnover rate and support business performance;

- business performance has a feedback cycle, having an impact on employee turnover and HC.
Literature analysis shows that further development of this topic is connected with the investigation of mediation and moderation effects in the "HC-performance" link. The examples of such studies are as follows: "Organizational support for intrapreneurship and its interaction with human capital to enhance innovative performance" published in Management Decision by [Alpkan et al., 2010], "Transformational leadership and employee creativity: Mediating role of creative self-efficacy and moderating role of knowledge sharing" published in Management Decision by [Mittal, Dhar, 2015].

Considering the development of topic 1 in analyzed journals, one could observe the upward trend in the Journal of Intellectual Capital towards leading position (see Fig. 8b), while in Management Decision and Journal of Knowledge Management topic on human capital takes the second place and in Measuring Business Excellence the third. The list of top 5 cited papers during the last two years in Journal of Intellectual Capital shows that the first paper by [Dumay, La Torre, Farneti, 2019] found out that "the unanticipated consequences of dishonest behavior by managers and shareholders compels a new application of stewardship theory that works as an overarching guide for managerial behavior and disclosure" and the second position takes the article about 
Three most cited papers on topic 2

\begin{tabular}{l|l|l|c}
\hline \multicolumn{1}{c|}{ Author } & \multicolumn{1}{c|}{ Journal } & \multicolumn{1}{c}{ Title } & Number of citations \\
\hline $\begin{array}{l}\text { [Ardichvili, } \\
\begin{array}{l}\text { Page, } \\
\text { Wentling, } \\
\text { 2003] }\end{array}\end{array}$ & $\begin{array}{l}\text { Journal of Knowledge } \\
\text { Management }\end{array}$ & $\begin{array}{l}\text { "Motivation and barriers to partici- } \\
\text { pation in virtual knowledge-sharing } \\
\text { communities of practice” }\end{array}$ & 931 \\
\hline $\begin{array}{l}\text { [Holste, } \\
\text { Fields, 2010] }\end{array}$ & $\begin{array}{l}\text { Journal of Knowledge } \\
\text { Management }\end{array}$ & $\begin{array}{l}\text { “Trust and tacit knowledge sharing } \\
\text { and use” }\end{array}$ & 275 \\
\hline $\begin{array}{l}\text { [Lin, Lee, } \\
\text { 2005] }\end{array}$ & Management Decision & $\begin{array}{l}\text { "Impact of organizational learning } \\
\text { and knowledge management factors } \\
\text { on e-business adoption” }\end{array}$ & 233 \\
\hline
\end{tabular}

human intellect and artificial intelligence in social entrepreneurship by [Popkova, Sergi, 2020].

\section{Topic 2. Knowledge sharing, organizational learning: processes that drive performance}

The second topic derived through text analysis embraces IC-related processes that drive performance, in particular, knowledge sharing and organizational learning. According to Figure 8(a), this topic has the lowest position among four. It is explained by narrow focus and the existence of separate journals such as The Learning Organization, which publishes studies oriented to organizational learning. In comparison with organizational learning, the processes of knowledge sharing are more intensively discussed in four journals, which we have chosen for this literature review. In table 3 , one could see the three most cited papers during the last two decades.

The first paper [Ardichvili, Page, Wentling, 2003] appears very relevant for modern business digitalization. It discovers motivation and barriers to participation in virtual knowledge-sharing communities of practice discussing the qualitative study of Caterpillar Inc., a multinational corporation. Fear of criticism and misleading of community members was marked as barriers to knowledge sharing. The paper of [Riege, 2005] contains a literature review on knowledge sharing barriers identifying three types of them, such as individual, organizational and technological ones, and proposing that developing various kinds of trust might be a tool for knowledge sharing motivation. Later, J. Holste and D. Fields [Holste, Fields, 2010] empirically proved that affect-based trust has a more significant effect on willingness to share knowledge, while cognition-based belief influences more on willingness to use tacit knowledge. One more highly cited paper written by [Lin, Lee, 2005] underlines the importance of IC-related processes for company digitalization.

Recent articles continue to discover the phenomenon of knowledge sharing and organizational learning, but go more in-depth and consider specific contexts. For example, the paper by [Hernaus et al., 2019] got already almost 30 citations. It presents a new aspect in the field of knowledge transfer, in particular, Evasive Knowledge Hiding, and provides empirical evidence for academia, asking more than 200 scholars from European public and private business schools about the antecedents and tools for decreasing Evasive Knowledge Hiding. Another paper by [Le, Lei, 2019] examines the mediating role of knowledge sharing between 
Three most cited papers on topic 3

\begin{tabular}{l|l|l|c}
\hline \multicolumn{1}{c|}{ Author } & \multicolumn{1}{c|}{ Journal } & \multicolumn{1}{c}{ Title } & Number of citations \\
\hline $\begin{array}{l}\text { [Bontis, Keow, } \\
\text { Richardson, 2000] }\end{array}$ & $\begin{array}{l}\text { Journal of Intellectual } \\
\text { Capital }\end{array}$ & $\begin{array}{l}\text { "Intellectual capital and business } \\
\text { performance in Malaysian industries” }\end{array}$ & 760 \\
\hline [Darroch, 2005] & $\begin{array}{l}\text { Journal of Knowledge } \\
\text { Management }\end{array}$ & $\begin{array}{l}\text { "Knowledge management, innovation } \\
\text { and firm performance” }\end{array}$ & 622 \\
\hline $\begin{array}{l}\text { [Chen, Cheng, } \\
\text { Hwang, 2005] }\end{array}$ & $\begin{array}{l}\text { Journal of Intellectual } \\
\text { Capital }\end{array}$ & $\begin{array}{l}\text { "An elationshical investigation of the } \\
\text { capital and firms' market value and } \\
\text { financial performance" }\end{array}$ & 514 \\
\hline
\end{tabular}

transformational leadership and innovation capabilities of a company.

\section{Topic 3. IC and KM for business performance}

This topic is the widest one and contains all studies devoted to the link between IC, KM, and business performance. Empirical evidence was the most demanded research at the beginning of the 2000s. Three most cited papers on topic three, such as [Bontis, Keow, Richardson, 2000; Chen, Cheng, Hwang, 2005; Darroch, 2005], confirmed the significant positive impact of IC and $\mathrm{KM}$ on business performance. Table 4 gives a list of these studies.

The first study analyzed the 107 responses of Malaysian companies and investigated the impact of different IC components, such as human capital, structural capital, and customer capital, on business performance. It was published in the first issue of the Journal of Intellectual Capital and started till now open academic discussion on empirical evidence of the IC role for business performance. The second study by [Darroch, 2005] is based on a sample of more than 400 companies from New Zeeland and reported on the imperative importance of knowledge for innovation. The third study [Chen, Cheng, Hwang, 2005] provides an example of big samples used in IC research due to the available data for IC measure- ments. It estimated the relationship between value added intellectual coefficient and companies' market value for more than 400 Taiwanese companies for ten years.

Two decades IC-related empirical research story confirmed, firstly, that the results of such studies are metrics sensitive [Molodchik, Shakina, Barajas, 2014] and, secondly, that contextual factors such as industry, region, country, company age, and size have a significant influence on ICbased performance [Pedro, Leitão, Alves, 2018; Molodchik, Jardon, Bykova, 2019]. Among recent high-cited publications, one can find the study of the moderation role of KM on the link between big data analytics and business performance [Ferraris et al., 2019].

\section{Topic 4. Measurement, disclosure of IC and knowledge for business performance}

The first question, which was asked by scholars in developing of IC concept, concerned the measurement of intangibles. That is why topic 4 takes the highest rank at the very beginning of IC related studies (see Fig. 8(a)). Moreover, one of the first articles published on IC by [Bontis, 1998] was devoted to the topic of measurements and further received high recognition through more than 1200 citations. In the first volume of the Journal of Intellectual Capital two authors [Petty,

PЖM 18 (3): 433-456 (2020) 
Three most cited papers on topic 4

\begin{tabular}{l|l|l|c}
\hline \multicolumn{1}{c|}{ Author } & \multicolumn{1}{c|}{ Journal } & \multicolumn{1}{c}{ Title } & Number of citations \\
\hline $\begin{array}{l}\text { [Guthrie, Petty, } \\
\begin{array}{l}\text { Yongvanich, } \\
\text { Ricceri, 2004] }\end{array}\end{array}$ & $\begin{array}{l}\text { Journal of Intellectual } \\
\text { Capital }\end{array}$ & $\begin{array}{l}\text { "Using content analysis as a } \\
\text { research method to inquire into } \\
\text { intellectual capital reporting” }\end{array}$ & 503 \\
\hline $\begin{array}{l}\text { [Guthrie, Petty, } \\
2000]\end{array}$ & $\begin{array}{l}\text { Journal of Intellectual } \\
\text { Capital }\end{array}$ & $\begin{array}{l}\text { "Intellectual capital: Australian } \\
\text { annual reporting practices" }\end{array}$ & 387 \\
\hline [Bontis, 2003] & $\begin{array}{l}\text { Journal of Intellectual } \\
\text { Capital }\end{array}$ & $\begin{array}{l}\text { "National Intellectual Capital Index: } \\
\text { A United Nations initiative for the } \\
\text { Arab region" }\end{array}$ & 302 \\
\hline
\end{tabular}

Guthrie, 2000], published literature review on IC measurement, reporting, and management underlining that measurement has a significant priority in the IC field. This article was cited 659 times.

As one can see from Fig. 8(b) the journal Measuring Business Excellence during the first decade was strongly oriented to the fourth topic, which corresponds with the scope of the journal. Now it takes the second position being behind the third more general topic. In the Management Decision and Journal of Knowledge Management topic four have the lowest position due to the journal scope.

The analysis of the citation report allows to identify the articles most cited during the last two decades (see Table 5).

J. Guthrie is one of the most-cited authors in the field of IC reporting. One could follow the evolution of this field using J. Guthrie's studies. Together with R. Petty [Guthrie, Petty, 2000], they analyzed Australian annual reporting practices and further presented content analysis as a tool for investigation of IC reporting [Guthrie et al., 2004]. During the next 15 years, there were many research efforts applied to IC disclosure, answering the questions:

- what is IC-related information worth to disclose;

- does IC disclosure have an impact on company performance;

- what kind of techniques should be applied for the analysis of IC disclosure?
A structured literature review [Cuozzo et al., 2017] sheds light on these questions and points to future research avenues. The recent paper [Parshakov, Shakina, 2020] proposes the exploratory design of content analysis by adopting LASSO regression and demonstrating which narrative constructs point out the intangible-intensiveness of corporations disclosed in their annual reports.

The third paper [Bontis, 2003] reflects a very promising topic of IC measurement at different levels. The recently published article [Pedro, Leitão, Alves, 2018] on IC at organizational, regional, and national levels confirms the role of IC for wealth creation beyond organizational boundaries.

\section{CONCLUSION AND DISCUSSION}

In trying to fill in the gap of the literature review studies on IC and intangible-driven performance, this paper has brought to the further discussion findings on the content analysis of more than 2400 papers published in four leading peer-review academic journals specialized in the field. The study aimed at providing a more profound understanding of the rapid evolution of the newly born IC concept during the last twenty years. The combination of text-mining tools and qualitative interpretive analytics of the key research topics and the most impactful papers within each of them allowed a ho- 
listic picture of the critical advancements and trends in IC-related studies. This study, on the one hand, has advocated the majority of previously known results by [Serenko, Bontis, 2013; Inkinen, 2015; Snyder, 2019; Bellucci et al., 2020]. On the other hand, it has brought new insights into the new areas of improvement in the field of IC and corporate performance.

Highlighting the key findings of the relevant literature exploration, we may suggest the following conclusions.

- The outlets - Management Decisions and Journal of Knowledge Management are among the leaders of contributions in ICrelated studies both for the number of papers and authors. Journal of Intellectual Capital can be considered, meanwhile, a breakthrough according to a growing impact in the field having a high number of the most influential recent papers. It has created both a strong reputation and high recognition of the outlet. Measuring Business Excellence being a rather general-interest journal in management studies demonstrates high interest likewise to IC studies.

- The confirmatory content analysis has shown:

- that there is a definite growing interest to innovative firms regardless of their size in the IC-related contributions in general. Meanwhile, there is a particular specialization of the outlets. So that, Journal of Intellectual Capital and Management Decisions are more welcoming studies on SMEs;

- that looking precisely at the dynamics of the performance measurement utilized, we witness the dominance of account-based indicators such as ROA and the growing relevance of value-based metrics - EVA and MVA;

- that surveys and self-reported data are clearly dominating the majority of quantitative IC-related studies. Meanwhile, case-studies that used to be the key methodological base for the Journal of Knowledge Management are now widely presented in the Journal of Intellectual Capital;

- that all analyzed outlets are shifting towards higher complexity of research designs and methods employed and become more demanding for new contexts analysis. For that reason, mediation and moderation effects can be met in the vast majority of recent empirical papers published in these journals.

- The exploratory content analysis suggested four relevant topics in IC-related studies. That set of the most frequent jointly met words and collocations brought us to the formulation of the following subtopics in IC studies: "Human capital and performance"; "Knowledge sharing, organizational learning: processes that drive performance"; "IC and knowledge management for business performance"; "Measurement, disclosure of IC and knowledge for business performance". Having very close relevance, there are still some trends in the growing popularity of intangible-driven performance and disclosure studies, especially in the Journal of Intellectual Capital importantly that this finding is coherent to the results demonstrated in the well-known papers by [Dumay, Garanina, 2013; Cuozzo et al., 2017] and a recent contribution by [Dumay, Guthrie, 2019].

The identification of the most impactful studies in each of the subtopics allowed tracking and forecasting of the future trends in IC-centered research. There is an evident trend in mixed-method methodology that combines data-rich empirics with profound qualitative interpretation and cross-checks with expert opinions. Meanwhile, experiments with new data settings may potentially represent the future trends in this topic. Furthermore, promising research contributions are associated with human capital research, which is considered the most fundamental and theoretically elaborated subareas of IC. As one can notice, methodological contributions are still on the upward trend since no universal solution for 
IC measurement has been proposed and validated so far. Also, decreasing trends for all performance indicators reflect the interest in the elaboration of new multidimensional metrics of company performance. However, the critical shift which must be anticipated, refers to more evident knowledge transfer to business and society. That implies a convergence of academic and applied research in IC-related papers.

Along with the contribution of this study, it is a subject of several limitations. The most important limitation is associated with the selection of the outlets for the analysis. Despite evidence-based reasoning behind this selection introduced in the first section, we admit that it may bring certain

\section{REFERENCES}

Abeysekera I. 2006. The project of intellectual capital disclosure: Researching the research. Journal of Intellectual Capital 7 (1): 61-75. https://doi.org/10.1108/146919306106 39778

Alpkan L., Bulut C., Gunday G., Ulusoy G., Kilic K. 2010. Organizational support for intrapreneurship and its interaction with human capital to enhance innovative performance. Management Decision 48 (5): $732-755$

Ardichvili A., Page V., Wentling T. 2003. Motivation and barriers to participation in virtual knowledge-sharing communities of practice. Journal of Knowledge Management 7 (1): 64-77. https://doi.org/10.1108/ 13673270310463626

Arun R., Suresh V., Veni Madhavan C. E., Narasimha Murthy M. N. 2010. On finding the natural number of topics with latent Dirichlet allocation: Some observations. In: M. J. Zaki, J. Xu Yu, B. Ravindran, V. Pudi (eds). Advances in Knowledge Discovery and Data Mining, 391-402. Springer Ber- controversy. However, this limitation brings opportunities for a deeper examination of topics, papers and trends in the IC-related studies. The formal analysis demonstrates that four outlets as selected for this paper cover a representative share of the most impactful papers in the field of IC-driven performance (more than 60\%).

Another essential limitation refers to the interpretation of the results of the topic modeling. This step of the analysis implied qualitative analysis and brings a certain level of subjectivity. Nevertheless, further analysis of the most relevant papers demonstrates that the identified research topics are supported by the papers with a high impact on the entire research area. lin Heidelberg. https://doi.org/10.1007/ 978-3-642-13657-3_43

Asmussen C. B., Møller C. 2019. Smart literature review: A practical topic modeling approach to exploratory literature review. Journal of Big Data 6 (1). https://doi. org/10.1186/s40537-019-0255-7

Barajas A., Shakina E., Fernández-Jardón C. 2017. Acceleration effect of intangibles in the recovery of corporate performance after-crisis. Research in International Business and Finance 42: 11151122. http://dx.doi.org/10.1016/j.ribaf. 2017.07.046

Barney J. 1991. Firm Resources and Sustained Competitive Advantage. Journal of Management 17 (1): 99-120. https://doi. org $/ 10.1177 / 014920639101700108$

Bellucci M., Marzi G., Orlando B., Ciampi F. 2020. Journal of Intellectual Capital: A review of emerging themes and future trends. Journal of Intellectual Capital (ahead-ofprint). https://doi.org/10.1108/JIC-102019-0239 
Bhatt G. D. 2001. Knowledge management in organizations: Examining the interaction between technologies, techniques, and people. Journal of Knowledge Management 5 (1): 68-75. https://doi.org/10.1108/ 13673270110384419

Bontis N. 1998. Intellectual capital: An exploratory study that develops measures and models. Management Decision 36 (2): 63-76. https://doi.org/10.1108/0025174 9810204142

Bontis N., Keow W. C. C., Richardson S. 2000. Intellectual Capital and Business Performance in Malaysian industries. Journal of Intellectual Capital 1 (1): 85-100.

Bontis N., Fitz-enz J. 2002. Intellectual capital ROI: A causal map of human capital antecedents and consequents. Journal of Intellectual Capital 3 (3): 223-247. https:// doi.org/10.1108/14691930210435589

Burgman R., Roos G. 2004. Measuring, managing, and delivering value performance in the public sector. International Journal of Learning and Intellectual Capital 1 (2): 132-149. https://doi.org/10.1504/IJLIC. 2004.005068

Cao J., Xia T., Li J., Zhang Y., Tang S. 2009. A density-based method for adaptive LDA model selection. Neurocomputing 72 (7-9): 1775-1781. https://doi.org/10.1016/j.neucom.2008.06.011

Chen M.-C., Cheng S.-J., Hwang Y. 2005. An empirical investigation of the relationship between intellectual capital and firms' market value and financial performance. Journal of Intellectual Capital 6 (2): 159176. https://doi.org/10.1108/14691930 510592771

Cook S., Brown S. 1999. Bridging epistemologies: The generative dance between organizational knowledge and organizational knowing. Organization Science 10 (4): 381-400. https://doi.org/10.1287/orsc.10.4. 381

Cuozzo B., Dumay J., Palmaccio M., Lombardi R. 2017. Intellectual capital disclosure: A structured literature review. Journal of Intellectual Capital 18 (1): 9-28. https://doi. org/10.1108/JIC-10-2016-0104
Darroch J. 2005. Knowledge management, innovation, and firm performance. Journal of Knowledge Management 9 (3): 101115. https://doi.org/10.1108/1367327 0510602809

Delbecque V., Bounfour A., Barreneche A. 2015. Intangibles and value creation at the industrial level: Delineating their complementarities. In: B A. Bounfour, T. Miyagawa (eds). Intangibles, Market Failure and Innovation Performance; 27-56. Springer International Publishing: N.Y. https:// doi.org/10.1007/978-3-319-07533-4_3

Deveaud R., SanJuan E., Bellot P. 2014. Accurate and effective latent concept modeling for ad hoc information retrieval. Document Numérique 17 (1): 61-84.

Dumay J. 2016. A critical reflection on the future of intellectual capital: From reporting to disclosure. Journal of Intellectual Capital 17 (1): 168-184.

Dumay J., Garanina T. 2013. Intellectual capital research: A critical examination of the third stage. Journal of Intellectual Capital 14 (1): 10-25.

Dumay J., Guthrie J. 2019. Reflections on interdisciplinary critical intellectual capital accounting research: Multidisciplinary propositions for a new future. Accounting, Auditing Accountability Journal 32 (8): 2282-2306. https://doi.org/10.1108/AAAJ08-2018-3636

Dumay J., Guthrie J., Ricceri F., Nielsen C. 2017. The past, present, and future for intellectual capital research: An overview. Routledge Companion To Intellectual Capital.

Dumay J., La Torre M., Farneti F. 2019. Developing trust through stewardship: Implications for intellectual capital, integrated reporting, and the EU Directive 2014/95/ EU. Journal of Intellectual Capital 20 (1): 11-39. https://doi.org/10.1108/JIC-062018-0097

Edvinsson L., Malone M. 1997. Intellectual Capital: Realizing Your Company's True Value by Finding Its Hidden Brainpower. HarperCollins: N.Y.

Ferraris A., Mazzoleni A., Devalle A., Couturier J. 2019. Big data analytics capabilities 
and knowledge management: Impact on firm performance. Management Decision 57 (8): 1923-1936. https://doi.org/10.1108/ MD-07-2018-0825

Grant R. M. 1991. The Resource-Based Theory of Competitive Advantage: Implications for Strategy Formulation. Available at: http://papers.ssrn.com/abstract $=\mathbf{1 5 0}$ 4481

Greve H. R. 2003. A behavioral theory of RD expenditures and innovations: Evidence from shipbuilding. The Academy of Management Journal 46 (6): 685-702. https:// doi.org/10.2307/30040661

Griffith D. A. 2010. An analytical perspective on sporting events attendance: The $2007-$ 2008 US NCAA college bowl games. Applied Geography 30 (2): 203-209. https:// doi.org/10.1016/j.apgeog.2009.01.005

Guthrie J., Petty R. 2000. Intellectual capital: Australian annual reporting practices. Journal of Intellectual Capital 1 (3): 241251. https://doi.org/10.1108/14691930 010350800

Guthrie J., Petty R., Yongvanich K., Ricceri F. 2004. Using content analysis as a research method to inquire into intellectual capital reporting. Journal of Intellectual Capital 5 (2): 282-293. https://doi.org/ 10.1108/14691930410533704

Hernaus T., Cerne M., Connelly C., Poloski Vokic N., Škerlavaj M. 2019. Evasive knowledge hiding in academia: When competitive individuals are asked to collaborate. Journal of Knowledge Management 23 (4): 597-618. https://doi.org/10.1108/JKM11-2017-0531

Holste J. S., Fields D. 2010. Trust and tacit knowledge sharing and use. Journal of Knowledge Management 14 (1): 128-140. https://doi.org/10.1108/136732710110 15615

Inkinen H. 2015. Review of empirical research on intellectual capital and firm performance. Journal of Intellectual Capital $\mathbf{1 6}$ (3): 518-565. https://doi.org/10.1108/ JIC-01-2015-0002

Intangible Asset Market Value Study. 2017. Ocean Tomo. [Electronic resource]. https:// www.oceantomo.com/intangible-asset-market-value-study/ (accessed: 11.05.2020).

Ittner C. D., Larcker D. F. 2001. Assessing empirical research in managerial accounting: A value-based management perspective. Journal of Accounting and Economics 32 (1): 349-410. https://doi.org/10.1016/ S0165-4101[01]00026-X

Jasimuddin S. M., Klein J. H., Connell C. 2005. The paradox of using tacit and explicit knowledge: Strategies to face dilemmas. Management Decision 43 (1): 102112. https://doi.org/10.1108/0025174 0510572515

Krippendorff K. 1980. Content Analysis: An Introduction to Its Methodology.

Kristandl G., Bontis N. 2007. Constructing a definition for intangibles using the resource-based view of the firm. Management Decision 45 (9): 1510-1524. https:// doi.org/10.1108/00251740710828744

Le P. B., Lei H. 2019. Determinants of innovation capability: The roles of transformational leadership, knowledge sharing, and perceived organizational support. Journal of Knowledge Management 23 (3): 527547. https://doi.org/10.1108/JKM-09-20180568

Lin H., Lee G. 2005. Impact of organizational learning and knowledge management factors on e-business adoption. Management Decision 43 (2): 171-188. https:// doi.org/10.1108/00251740510581902

Ming-Chin Ch., Shu-Ju Ch., Yuhchang H. 2005. An empirical investigation of the relationship between intellectual capital and firms' market value and financial performance. Journal of Intellectual Capital 6 (2): 159-176. https://doi.org/10.1108/14 691930510592771

Mittal S., Dhar R. L. 2015. Transformational leadership and employee creativity: Mediating role of creative self-efficacy and moderating role of knowledge sharing. Management Decision 53 (5): 894-910. https://doi. org/10.1108/MD-07-2014-0464

Molodchik M., Jardon C. M., Bykova A. 2019. The performance effect of intellectual capital in the Russian context: Industry vs. 
company level. Journal of Intellectual Capital 20 (3): 335-354. https://doi.org/ 10.1108/JIC-10-2018-0190

Molodchik M., Jardon C. M. 2017. Intellectual capital as an enhancer of product novelty: An empirical study of Russian manufacturing SMEs. Journal of Intellectual Capital 18 (2): 419-436.

Molodchik M., Shakina E., Barajas A. 2014. Metrics for the elements of intellectual capital in an economy driven by knowledge. Journal of Intellectual Capital 15 (2): 206226.

Molodchik M., Shakina E., Bykova A. 2012. Intellectual capital transformation evaluating model. Journal of Intellectual Capital 13 (4): 444-461. https://doi.org/10.1108/ 14691931211276089

Nahapiet J., Ghoshal S. 1998. Social capital, intellectual capital, and the organizational advantage. The Academy of Management Review 23 (2): 242-266. https://doi.org/ 10.5465/AMR.1998.533225

Naidenova I., Parshakov P. 2013. Intellectual capital investments: Evidence from panel VAR analysis. Journal of Intellectual Capital 14 (4): 634-660. https://doi.org/10.1108/ JIC-01-2013-0011

Osinski M., Selig P. M., Matos F., Roman D. J. 2017. Methods of evaluation of intangible assets and intellectual capital. Journal of Intellectual Capital 18 (3): 470485. https://doi.org/10.1108/JIC-12-20160138

Parshakov P., Shakina E. 2020. Do companies disclose intellectual capital in their annual reports? New evidence from explorative content analysis. Journal of Intellectual Capital 21 (6) 853-871. https://doi.org/ 10.1108/JIC-03-2019-0040

Pedro E., Leitão J., Alves H. 2018. Back to the future of intellectual capital research: A systematic literature review. Management Decision 56 (11): 25022583. https://doi.org/10.1108/MD-082017-0807

Petty R., Guthrie J. 2000. Intellectual capital literature review: Measurement, reporting, and management. Journal of Intellectual
Capital 1 (2): 155-176. https://doi.org/ 10.1108/14691930010348731

Popkova E. G., Sergi B. S. 2020. Human capital and $\mathrm{AI}$ in industry 4.0. Convergence and divergence in social entrepreneurship in Russia. Journal of Intellectual Capital 21 (4): 565-581. https://doi.org/10.1108/ JIC-09-2019-0224

Riege A. 2005. Three-dozen knowledge-sharing barriers managers must consider. Journal of Knowledge Management 9 (3): 1835. https://doi.org/10.1108/136732705 10602746

Serenko A., Bontis N. 2013. Investigating the current state and impact of the intellectual capital academic discipline. Journal of Intellectual Capital 14 (4): 476-500. https:// doi.org/10.1108/JIC-11-2012-0099

Shakina E., Barajas A. 2012. The relationship between intellectual capital quality and corporate performance: An empirical study of Russian and European companies. Economic Annals 57 (192): 79-97. https://doi. org/10.2298/EKA1292079B

Shakina E., Barajas A. 2014. Value creation through intellectual capital in developed European markets. Journal of Economic Studies 41 (2): 272-291. https://doi.org/ 10.1108/JES-08-2012-0122

Shakina E., Barajas A. 2015. Intangible-intensive profile of a company: The key to outperforming. Journal of Intellectual Capital 16 (4): 721-741. https://doi.org/10.1108/ JIC-03-2015-0025

Shakina E., Barajas A. 2016. Intangible-intensive profiles of companies: Protection during the economic crisis of 2008-2009. Journal of Intellectual Capital 17 (4): 758775. https://doi.org/10.1108/JIC-02-20160029

Shakina E., Molodchik M. 2014. Intangibledriven value creation: Supporting and obstructing factors. Measuring Business Excellence 18 (3): 87-100. https://doi.org/ 10.1108/MBE-12-2013-0063

Silge J., Robinson D. 2016. Text mining and analysis using tidy data principles in $\mathrm{R}$. The Journal of Open Source Software 1 (3): 37. https://doi.org/10.21105/joss.00037 
Smith E. A. 2001. The role of tacit and explicit knowledge in the workplace. Journal of Knowledge Management 5 (4): 311-321. https://doi.org/10.1108/136732701104 11733

Snyder H. 2019. Literature review as a research methodology: An overview and guidelines. Journal of Business Research 104: 333-339. https://doi.org/10.1016/j.jbusres. 2019.07.039

Stern J. M., Shiely J. S., Ross I. 2001. The EVA Challenge: Implementing Value-Added Change in an Organization. Wiley and Co: N.Y.

Teece D. J., Pisano G., Shuen A. 1997. Dynamic capabilities and strategic management. Strategic Management Journal 18 (7): 509-533.
Yahya S., Goh W. 2002. Managing human resources toward achieving knowledge management. Journal of Knowledge Management 6 (5): 457-468. https://doi.org/10.1108/ 13673270210450414

Young S. D., O'Byrne S. F. 2000. EVA and Value-Based Management: A Practical Guide to Implementation. McGraw Hill Professional: N.Y.

Zaratiegui J. M. 2002. What does profit mean for Alfred Marshall? International Journal of Applied Economics and Econometrics $\mathbf{1 0}$ (3): 381-402. Available at: https://dadun. unav.edu/handle/10171/6286

Zucker L. G., Darby M. R., Brewer M. B. 1998. Intellectual human capital and the birth of U.S. biotechnology enterprises. American Economic Review 88 (1): 290-306

Initial Submission: August 17, 2020

Final Version Accepted: October 13, 2020

Нелатериальнье ресурсь и результаты деятельности: два десятилетия в поисках философского калня*

\section{Е. А. Шакина}

Национальный исследовательский университет «Высшая школа экономики», СанктПетербург, Россия

\section{М. А. Молодчик, П. А. Паршаков}

Национальный исследовательский университет «Высшая школа экономики», г. Пермь, Россия

В исследовании представлен обзор литературы, посвященной 20 -летней эволюции нового и быстроразвивающегося направления исследований интеллектуального капитала и результатов деятельности компаний. $\kappa$ настоящему времени концепция интеллектуального капитала претерпела существенную трансформацию, что вызвало широкую научную дискуссию, повлекшую за собой публикацию большого числа эмпирических и методологических работ. Несмотря на то что в указанный период появилось несколько попыток систематизировать знания об интеллектуальном капитале в рамках обзорных работ, целостное представление о наиболее значимых трудах и перспективах развития темы пока не создано. Для описания всего спектра исследований в области интеллектуального капитала и связанных с ним ре-

\footnotetext{
* Исследование выполнено при финансовой поддержке гранта РФФИ, проект №19-110-50417.
} 
зультатов деятельности компаний в статье используется так называемая смешанная исследовательская методология, охватывающая инструменты как машинного обучения, так и углубленной качественной интерпретации полученных результатов, включающей элементы критического анализа наиболее значимых работ в области интеллектуального капитала. В результате предложены четыре научные темы, выявленные на основе метода интеллектуального анализа текстов “topic modeling”: «Человеческий капитал и производительность», «Обмен знаниями, организационное обучение: процессы, определяющие производительность», «Интеллектуальный капитал и управление знаниями для эффективности бизнеса», «Измерение и раскрытие интеллектуального капитала и корпоративных знаний». Все указанные темы приветствуются ключевыми ведущими журналами в исследуемой области - Journal of Intellectual Capital, Journal of Knowledge Management, Management Decision u Measuring Business Excellence - и имеют высокий потенциал для появления концептуальных и эмпирических работ, а также практическую ценность для бизнеса в условиях новой экономики.

Ключевые слова: литературный обзор, результаты деятельности, интеллектуальный капитал, интеллектуальный анализ текстов, тематическое моделирование.

JEL: J24, L25, O34.

For citation: Shakina E. A., Molodchik M. A., Parshakov P. A. 2020. Intangible-driven performance: Two decades searching for the Philosopher's Stone. Russian Management Journal 18 (3): 433-456.

Статья поступила в редакиию 17 августа 2020 г. Принята к публикации 13 октября 2020 2. 